\title{
Mexico's Glaciers and their Close Disappearance: A Precise Thermometer of the Global Warming Advance on a Global Scale
}

\author{
RAMIRO RAMIREZ NECOECHEA ${ }^{1 *}$, ISABEL VALENZUELA MERAZ ${ }^{2}$ \\ and JOSE FRANCISCO HERNANDEZ RAMIREZ ${ }^{3}$
}

\author{
'Departamento De Producción Agrícola Y Animal, Universidad Autónoma Metropolitana, \\ Xochimilco, Calzada Del Hueso 1100, Col. Villa Quietud, Delegación Coyoacán, C.P. 04960, México. \\ 2Universidad Juárez Del Estado De Durango, Constitución 404 Sur Zona Centro, \\ C.P. 34000 Durango, Dgo. México. \\ ${ }^{3}$ Facultad De Estudios Superiores Zaragoza, UNAM. Batalla 5 De Mayo S/N Esq. \\ Fuerte De Loreto, Col. Ejército De Oriente, México.
}

http://dx.doi.org/10.12944/CWE.8.3.07

(Received: September 16, 2013; Accepted: October 20, 2013)

\begin{abstract}
Maxican glaciers of the Iztaccihutl, Orizaba's peak (Citlaltepetl) and pococatepetl will disappear in the next 10 to 35 years, warms a study from the National Autonomous University of Mexico (UNAM) (Lorenzo 1964)
\end{abstract}

Key words : Mexico's Glaciers, Global Warming, Iztaccihuatl.

\section{INTRODUCTION}

Mexican glaciers of the Iztaccihuatl, Orizaba's peak (Citlaltepetl) and Popocatepetl will disappear in the next 10 to 35 years, warns a study from the National Autonomous University of Mexico (UNAM) (Lorenzo 1964).

Mexico's Glaciers focalize an unusual global interest, on one hand; they are the only one in latitude $19^{\circ}$ north and exist due to the mountains that allocate then have heights higher than 5000 meters. International organization studying global climate change (World Glacier Monitoring Service and World Meteorological Organization), among others, consider the analysis of their behavior as one of the best global climate indicators of climate change (White 1954).

In this context, our glaciers became the most exact global climate measure tools in their latitude. On the other hand, some are located over active volcanoes and therefore, there is the chance that an eruptive reactivation generates volcanic detritus flux events that can result catastrophic, as an example of this: in 1985, The Nevado del Ruiz in Colombia (mountain of similar height to Popocatepetl), had a relatively small eruption and generated an event that buried almost 20 thousand people from the near town of Armero. In Mexico having similar circumstances is impossible, given the distance of the population to the glaciers, never the less the volcanoes with glaciers are studied closely. The best studied is the Popocatepetl's; it's eruption on December 1994 awoke great interest in the glacier behavior, combined with the eruptive activity (Delgado 1997).

Likewise the glaciers in Mexico, there is the risk that in the next years countless ice reserves in Latin-American mountains disappear.

The information becomes worrisome for both of the tropics, only in Peru there's been more 
than 145 lost glaciers in the last decades; Peru is the Latin-America country with the most ice bodies in the heights.

Bolivia is in the same situation; it registered the nearly total extinction of the ice body of the Chacaltaya Mountain and left almost waterless the La Paz and Los Altos Cities.

The first Mexican glacier inventory was made by Dr. Jose Luis Lorenzo (1959) who pointed that in 1958 the total glacier area in the Popocatepetl was $0.89 \mathrm{Km} 2$; the second inventory (in 1982), determined $0.56 \mathrm{Km} 2$, and the third inventory (in 1996), $0.53 \mathrm{Km} 2$. In 2000 it had the $30 \%$ of the 1958 registered area and $44 \%$ was lost between 1996 and 2000. The ablation-accumulation cycle broke since 1996, given that the glaciers only lost mass and didn't recover ice. In visited sites in 1995 the ice had a thickness of 40 meters; in 2000 only 4. This allowed documenting the accelerated extinction of the Popocatepetl glaciers on the late 2000 (Delgado 1997). The ice remnants that are still visible, scarcely fulfill the glacier characteristics, and are seracs only (independent blocks of ice), that hang unstably and keep melting without the characteristic glacier movement. It's worth mentioning that the Popocatepetl extinction is due to three factors: Global Climate Change, Big population centers influence and eruptive activity. Even if these glaciers were close to disappearing due to the first two, the acceleration occurred due to the eruptive activity.

To quantify the climate change and the population centers influence in this process studies are being conducted on Citlaltepetl (Palacios 1996) andthis investigation raises questions on the possible future impact of the end of the ice bodies, as a consequence of eliminating a source of aquifers recharge and the danger the seracs represent, along with the eruptive activity for mountaineers. The Mexican glaciers refuse to die, but will irremissibly extinguish. It's important to document this phenomenon, including its causes. The current results reflect great withdraw, for instance, Iztaccihuatl has a $20 \%$ glacier area loss in 24 years. It is predicted that it will disappear between 2020 and 2025 of earlier if the regions temperature keeps increasing. The Citlaltepetl glaciers are also withdrawing, but may live longer, even though its ice bodies are very vulnerable since they are thin and exposed to high temperatures.

\section{The Popocatepetl}

This volcano presents and will present even more seracs due to the eruption presented since 1994, which accelerated the glacier melting to near extinction, the glaciers threatened by global warming and volcanic activity are Ventorrillo's and Northeast glaciers, the last one has diminished it's extension to almost disappearance; meanwhile the North glacier's characteristic fissures have deepened importantly until diminishing the glacier thickness and extension in more than $50 \%$.

\section{The Iztaccihuatl}

The problem with this volcano is altitude, its glaciers are below the $\mathbf{5 2 0 0}$ meter bench mark, that it's the peak of the mountain, at this height the snow bodies are highly vulnerable to tropic climate degradation. The temperature of the ice bodies is near $0^{\circ} \mathrm{C}$, and the atmosphere temperature is higher, therefore not cold enough to preserve them; so, the ice bodies could disappear at any moment.

The Iztaccihuatl glaciers were twelve 40 years ago, and had the following names:

- $\quad$ Head glacier
- $\quad$ Neck glacier
- North glacier
- $\quad$ Nest glacier
- Oriental Center (Huilango) glacier
- $\quad$ Atzintli glacier
- San Agustin glacier

Of which Head and Neckand San Agustin are already gone, the rest of the ones over the 4800 AMSL benchmark are in great degradation. Of these the biggest which are the Ayolotepito, Ayoloco or Piedra Lisa, Atzintli and Oriental Center have shrunk in more than $50 \%$ of the frozen water storage capacity compared to which they had 40 years ago. 


\section{The Citlaltepetl}

The future for the Citlaltepetl of Orizaba's Peak is a bit more encouraging, even though no precise estimation is available, it's been calculated its glaciers can live until around 2040, because they are located at 5700 , which allows more ice accumulation.

Even with this fact, there are glaciers that are mostly gone, since only some remnants are left and are basically the occidental side of the volcano, these are:

\section{- Bull glacier \\ - Beard glacier \\ - Northeast glacier \\ - West glacier \\ - Southwest glacier}

In the oriental side the oriental and east glaciers have survived but are on clear degradation. Meanwhile the glaciers of the north face, which are the Jamapa and Chichimeco ones, will subsist for the longest due to their ice volumes which are quite important.

However, the thickness of the ice sheetsof about 10 meters and with a maximum of 40 , and a temperature near 0 Celsius degrees, are still very vulnerable in tropical conditions.

\section{The Threat}

The issue is that with the melting of the ice bodies, the waters drain to the lakes, or form lagoons contained by moraines (natural damns made by eroded rocks and accumulated by glaciers).

However, these rock and ice deposits in their interstice suffer fusion due to climate warming and, as a result are weakened by natural damns, which represent a danger, since if they overboard or collapse a disaster could occur which more likely won't happen, since in Mexico the glaciers are too small, their gradual melting and their farness from the populated centers. Even though the solution would be to drain it, on the long run -with the disappearance of the glaciers-, the centers wouldn't count with water to feed the hydroelectric systems, and neither for direct human consumption and even less for livestock activities and agriculture.

In Mexico's case, gradual but constant ice body melting is present that show a warning that in the next three decades the Iztaccihuatl, Orizaba's peak and Popocatepetl glaciers can disappear as a consequence of global warming.

In conclusion the lack of water contribution from the glaciers will create supply problems in towns such as San Rafael, Tlalmanalco, Amecameca, Ozumba, San Pedro Nexapa, because they are the principal establishments highly dependent of the waters generated by the Iztaccihuatl and Popocatepetl glaciers, affecting considerably the porcine, dairy and poultry production of the zone.

The Iztaccihuatl and Popocatepetl oriental flow threatened the Puebla's valley aquifers recharge and the free rolling of superficial waters.

The disappearance of these glaciers is in synthesis a clear warning of the meaning that has and will have the global warming and its impact over macro and micro ecosystems in the side of the volcanoes of which important livestock production depend, such as porcine, wool, poultry and cattle and a great mass of human population, 4.5 million inhabitants (Aguirre 2012) closest to the volcano of which 7,000,000 stand in a high risk zone in case of Popocatepetl's eruptive activity, however the main threat is to protect against gases and ashes produced by low eruptive activity $25,000,000$ people who live around the Popocatepetl in cities on Mexico and Puebla.

\section{REFERENCES}

1. Aguirre Arvizu A. "Popocatepetl puts Mexico in alert"ContenidoNo. 588 ,pag 76-83 (2012).

2. Delgado Granados, H. "The glaciers of Popocatépetl volcano (Mexico): changes and causes." Quatermary international, 43/44:5360, (1997).

3. Lorenzo, J.L. "The Glaciers of Mexico."Geophysics Institute Monographs, 
U.N.A.M, 1; (1959).

4. Lorenzo, J.L. "The Glaciers of Mexico" (Second edition). Geophysics Institute Monographs, U.N.A.M, 1; (1964).

5. Palacios, D. and Vaquez-Selem, L. "Geomorphic effects of the retreat of Jamapa
Glacier, Pico de Orizava volcano.Mexico."Geografiska Annaler, 77A: 19-34 (1996).

6. White, S. E. "Neoglacial to recent glacier fluctuations on the volcano Popocatepetl, Mexico." Journal of Glaciology, 27(96); 359363, (1981). 